\title{
Parthenium hysterophorus Current Status and Its Possible Effects on Mammalians- A Review
}

\author{
Alka Sahrawat ${ }^{1}$, Jyoti Sharma ${ }^{1}$, Siddarth Nandan Rahul ${ }^{1 *}$, \\ Snigdha Tiwari ${ }^{1}$ and D.V. Rai ${ }^{2}$ \\ ${ }^{I}$ Department of Biotechnology, Agriculture and Agri-informatics, Shobhit Institute of \\ Engineering and Technology, Meerut, India \\ ${ }^{2}$ Shobhit University, Gangoh, Saharanpu, India
}

*Corresponding author

\begin{tabular}{|c|c|}
\hline & A B S T R A C T \\
\hline $\begin{array}{l}\text { Ke y w o r d s } \\
\text { Parthenium } \\
\text { hysterophorus, } \\
\text { Harmful effect, } \\
\text { Benefits, Biological } \\
\text { control }\end{array}$ & \multirow{3}{*}{$\begin{array}{l}\text { Parthenium hysterophorus perennial North American weed and known for its harmful } \\
\text { effects. It also has the other name like carrot weed, congress grass and one of the ten } \\
\text { feared noxious weed species in the world. It is harmful to all the living beings as it causes } \\
\text { various serious problems like asthma, bronchitis, dermatitis, and hay fever in human and } \\
\text { other mammalians and it has approximately devastated all the main crops and plants by } \\
\text { reducing the availability of nutrients and other through competing with the crop. So far, } \\
\text { attempts of developing effective control measure have not yielded any success. Not even a } \\
\text { single indigenous insect species has proved successful in spite of occurrence and } \\
\text { infestation by many species. Management options for parthenium include chemical, } \\
\text { grazing management, physical and biological methods (Dhileepan, 2009). As it has the } \\
\text { high generation and massive seed production capability makes it very hazardous in many } \\
\text { ways to the human and other mammalians. }\end{array}$} \\
\hline Article Info & \\
\hline $\begin{array}{l}\text { Accepted: } \\
\text { 25 October } 2018 \\
\text { Available Online: } \\
\text { 10 November } 2018\end{array}$ & \\
\hline
\end{tabular}

\section{Introduction}

Parthenium hysterophorus L. is from class Magnoliopsidaand member of Asteraceae family, a noxious weed, inhabits many parts of the world, in addition to its native range in North and South America and the West Indies (Picman and icman, 1984). Parthenium hysterophorus L. is originated as a result of natural hybridization between Parthenium confertum and Parthenium bipinnatifidum (Nath, 1988). It is commonly known as Carrot weed (English), Congress grass (English), False ragweed (English), Korottenkraut
(German), Parthenium weed (English), Bitter weed (English), Starweed (English), Faussecamomille (French-New Caledonia), Feverfew (English), Santa Maria feverfew (English) and White top weed (English) (Kumar 2014). Parthenium hysterophorus is found in Australia, Bangladesh, Ethiopia, India, Sri lanka, Kenya, Madagascar, Nepal, Pakistan, Papua New Guinea, Puerto Rico, South Africa, Swaziland, Taiwan, Vietnam and the United States. In India, it is locally known as 'Gajarghas'. Parthenium was introduced to India in seed form as a contaminant of food grains imported from 
Mexico. It is regarded as one of the worst weeds because of its invasiveness, potential for spread, and economic and environmental impacts, and it is noxious because it is highly adaptable to almost all type of environmental conditions, can invade all types of land, also causes high losses in the yield of field crops and direct contact with plant (Aneja et al., 1991) and (Auld et al., 1983). In India it has invaded almost all the states with a high level of spreading in Haryana, Punjab and U.P. It was first reported in India in 1880, but recognized as a threat in 1950s.

Parthenium hysterophorus is a prolific weed belonging to Asteraceae family, producing thousands of small white capitula each yielding five seeds on reaching maturity. Within the past century it has found its way to Africa, Australia, Asia and Pacific Islands and has now become one of the world's seven most devastating and hazardous weeds. This noxious weed is often spotted on abandoned lands, developing residential colonies around the towns, railway tracks, roads, drainage and irrigation canals, etc. This weed grows luxuriantly in established gardens, plantations and vegetable crops. Due to its high fecundity a single plant can produce 10,000 to 15,000 viable seeds and these seeds can disperse and germinate to cover large areas. This alien weed is believed to have been introduced into India as contaminants in PL 480 wheat (Public Law 480 passed in 1954 to give food grains to developing countries for eliminating starvation and malnutrition) imported from the USA in the 1950s. Presently, this invasive weed is widely prevalent in India (Singh et al., 2008). Approximately two million hectares of land in India have been infested with this herbaceous menace (Dwivedi et al., 2009).

Parthenium hysterophorus produces an array of secondary metabolites which adds to its aggressive nature in almost all habitats. Parthenin, hymenin, coronopilin, dihydroisoparthenin, hysterin, hysterophorin and tetraneurin are the principal constituents of the sesquiterpene lactones along with phytotoxic compounds like hysterin and ambrosin. Some of the flavonoids present are quercelagetin 3, 7-dimethylether, 6-hydroxyl kaempferol and 3-0 arabinoglucoside. The weed also produces phenol derivatives like caffeic, vanllic, ferfulic, chlorogenic and anisic acids along with some unidentified compounds. Parthenin, hymenin and ambrosin are reported to be responsible for the menacing role of this weed in provoking health hazards (Lata et al., 2008). In humans, they are the causative agents of allergic ailments like bronchitis, dermatitis and hay fever. Parthenin has been reported from almost all the plant parts including trichomes and pollen (Reinhardt et al., 2004; Sharma and Sethuraman, 2007). It also causes dermatitis in cattle and domestic animals. Though it is known for its harmful effects, but some useful properties such as insecticidal, nematicidal and herbicidal and its antimicrobial potential is also documented in literature (Oudhia and Tripathi, 1998a; Oudhia et al., 1997a and b).

\section{Habit and habitat}

It is an erect annual herb up to $2 \mathrm{~m}$ in height with a deep tap root and an erect stem that becomes woody with age. Leaves are pale green in color, lobed, hairy, alternate, sessile, irregularly dissected and bipinnate. The number of leaves per plant varies from 6 to 55 . The flowering starts about a month after germination with creamy white flower heads on the tips of numerous stems. Each flower contains four to five wedgeshaped black seeds, two millimeters long with two thin white scales. The plant is a prolific seed producer with single plant producing on an average 2,400-30,000 seeds during its life cycle (Haseler, 1976; Rodriguez and Cepero, 1984; Williams and Groves, 1980). The dispersal of its seed is via different means viz 
water currents, movement of vehicles, machinery, livestock, grain, stock feed and wind (Sankaran, 2008). Seeds are capable of germination over a broad range of humidity, $\mathrm{pH}$ and temperature but high soil moisture is suitable for seed germination (Ahlawat et al., 1979; Tamado et al., 2002; Singh et al., 2004).

\section{Chemical analysis of $\boldsymbol{P}$. hysterophorus}

Isolation and structural elucidation of the active principles of $P$. hysterophorus is required to determine their chemical properties. Chemical analysis of $P$. hysterophorus has indicated that all its parts including trichomes and pollen contain toxins called sesquiterpene lactones (SQL). Maishi et al., (1998) reported that $P$. hysterophorus contains a bitter glycoside parthenin, a major sesquiterpene lactone. Other phytotoxic compounds or allelochemicals are hysterin, ambrosin, flavonoids such as quercelagetin 3, 7-dimethylether, 6-hydroxyl kaempferol, 3-0 arabinoglucoside, fumaric acid. P-hydroxy benzoin and vanillic acid, caffeic acid, $p$ courmaric, anisic acid, p-anisic acid, chlorogenic acid, ferulic acid, sitosterol and some unidentified alcohols. Parthenin, hymenin and ambrosin are found to be the culprits behind the menacing role of this weed in provoking health hazards (Lata et al., 2008). Parthenium hysterophorus from different geographical regions exhibited parthenin, hymenin, coronopilin, dihydroisoparthenin, hysterin, hysterophorin and tetraneurin $\mathrm{A}$ as the principal constituents of their sesquiterpene lactones (De La Fuente et al., 1997). (Gupta et al., 1996) identified a novel hydroxyproline-rich glycoprotein as the major allergen in $P$. hysterophorus pollen. (Das et al., 2007) examined the flowers of $P$. hysterophorus and isolated four acetylated pseudoguaianolides along with several known constituents. A novel sesquiterpenoid, charminarone, the first secopseudoguaianolide, has been isolated along with several known compounds from the whole plant by (Venkataiah et al., 2003). (Chhabra et al., 1999) discovered three ambrosanolides from the chloroform extract of this weed.

\section{Health hazards to humans and livestock}

This weed is known to cause many health hazards which have now reached epidemic proportions. Agriculturists are concerned about $P$. hysterophorus affecting food and fodder crops, since the pollen and dust of this weed elicit allergic contact dermatitis in humans (Gunaseelan 1987; Morin et al., 2009). Dermatitis is a T cell-mediated immune injury and the disease manifests as itchy erythematous papules and papulovesicular lesions on exposed areas of the body (Akhtar et al., 2010). These effects have been related to cytotoxicity of the sesquiterpene lactone parthenin (Narasimban et al., 1984). Persons exposed to this plant for prolonged period manifest the symptoms of skin inflammation, eczema, asthma, allergic rhinitis, hay fever, black spots, burning and blisters around eyes. Parthenium hysterophorus also causes diarrhoea, severe popular erythematous eruptions, breathlessness and choking (Maishi et al., 1998).

Exposure to $P$. hysterophorus pollens causes allergic bronchitis (Towers and Subba Rao 1992). (Ramos et al., 2001) assessed the mutagenic potential of a crude extract of $P$. hysterophorus in the Salmonella/microsome (Ames) assay and the mouse bone marrow micronucleus test. However, it did not show genotoxic potential. (Sharma et al., 2005) observed that the clinical pattern of Parthenium dermatitis progresses from airborne contact dermatitis to mixed pattern or chronic actinic dermatitis pattern. Eczema herpeticum is reported to complicate parthenium dermatitis. (Sriramarao et al., 1993) worked on the use of murine polyclonal 
anti-idiotypic antibodies as surrogate allergens in the diagnosis of $P$. hysterophorus hypersensitivity.

\section{Biological control of $P$. hysterophorus weeds}

(Dhileepan2003a, b) studied the effectiveness of leaf-feeding beetle Zygogramma bicolorata, stem-galling moth Epiblema strenuana and stem-boring weevil Listronotus setosipennis introduced against $P$. hysterophorus in Australia. The moth Carmentaithacae and leaf-rust Puccinia melampodi were released to eliminate this weed, but little success has been attained in this regard as the weed has great regenerative potential and moreover the insect consumes only the foliage of the weed which stimulates further leafy proliferation (Dhileepan and Strathie 2009).

\section{Health benefits of $\boldsymbol{P}$. hysterophorus}

The decoction of $P$. hysterophorus has been used in traditional medicine to treat fever, diarrhoea, neurologic disorders, urinary tract infections, dysentery, and malaria as emmenagogue (Surib-Fakim et al., 1996). Ethnobotanically, it is used by some tribes as remedy for inflammation, eczema, skin rashes, herpes, rheumatic pain, cold, heart trouble and gynaecological ailments. Parthenium hysterophorus has been found to be pharmacologically active as analgesic in muscular rheumatism, therapeutic for neuralgia and as vermifuge (Maishi et al., 1998). This weed is also reported as promising remedy against hepatic amoebiasis. Parthenin, the major constituent of the plant, exhibits significant medicinal attributes including anticancer property (Venkataiah et al., 2003). The methanol extract of the flowers showed significant antitumour activity and parthenin exhibited cytotoxic properties against $\mathrm{T}$ cell leukaemia, HL-60 and Hela cancer cell lines (Das et al., 2007). Previously, (Ramos et al.,
2002) had established the antitumour potential of $P$. hysterophorus extracts in vitro and in vivo with positive results in terms of tumour size reduction and overall survival of cell lines. Aqueous extract of $P$. hysterophorus has hypoglycaemic activity against alloxaninduced diabetic rats (Patel et al., 2008). So, flower extract of this weed can be used for developing drug for diabetes mellitus.

\section{$P$. hysterophorus as substrate for enzyme production}

Xylanases are hydrolytic enzymes that cleave xylans. The end products of xylan degradation have industrial applications for biofuel, artificial sweetener, animal feed production, baking and textile industry, clarification of fruit juices and coffee extraction. Besides, there has been an increasing interest in using xylanases for ecofriendly bleaching of pulp in paper industries. The potential of $P$. hysterophorus as low-cost raw material for xylanase production was studied by (Dwivedi et al., 2009). They investigated xylanase production from a mutant of Penicillium oxalicum in submerged fermentation. Considerably higher level of the enzyme production in medium containing $P$. hysterophorus confirms the feasibility of using this cheap resource as an alternative carbon source to save costs of the enzyme production process (Dwivedi et al., 2009).

\section{$P$. hysterophorus as additive with cattle manure in biogas production}

In the wake of oil crisis, energy generation from biowastes by anaerobic digestion has attracted immense attention. Energy crops are likely to be future sources of digester feed stocks for methane generation. Parthenium hysterophorus was mixed with cattle manure at a $10 \%$ level and allowed to digest anaerobically at room temperature in 3-1 batch digesters. The chemical changes during the 
course of digestion and the effect of digested slurry (inoculum) on biogas production were investigated and significant increase in methane content was achieved. The methane content of the gas varied between 60 and $70 \%$ (Gunaseelan 1987).

\section{P. hysterophorus for welfare of livestock}

Parthenium hysterophorus can be used as a flea-repellent for dogs (Maishi et al., 1998). This weed is a valuable source of potash, oxalic acids and high-quality protein (HQP) which can be used in animal feed (Mane et al., 1986).

\section{Antimicrobial and Wound healing activity}

Hydroalcoholic extract of $P$. hysterophorus was in vitro effective against Plasmodium falciparum (Valdes et al., 2010). In vitro, this plant demonstrated antiamoebic activity comparable to the standard drug Metronidazole against axenic and polygenic cultures of Entamoeba histolytica, responsible for amoebiasis (Talakal et al., 1995) Fusarium wilt, an economically important fungal disease in potato caused by Fusarium solani was significantly inhibited by aqueous, methanol and n-hexane extracts (Zaheer et al., 2012).Externally leaf paste application of $P$. hysterophorus showed wound healing activity (Kumar et al., 2011).

\section{Antioxidant activity}

The antioxidant phytochemicals protect the cells from oxidative damage caused by free radicals. DPPH (2, 2-diphenyl-1picrylhydrazyl radical) scavenging assay revealed that Methanolic and ethanolic extract of Parthenium hysterophorus showed antioxidant activity 78.25561\% and66.28858\% respectively ( $\mathrm{N}$ et al., 2010). But next time acetone extract was found to have higher anti-oxidant activity than methanol and chloroform extracts (Priya et al., 2011). $200 \mathrm{mg} / \mathrm{kg}$ of body weight of fresh leaves ethanolic extract has been showed significant antioxidant activity in rats (Pandey et al., 2012).

\section{Hypoglycemic activity}

Administration of aqueous extract of $P$. hysterophorus flower (100 mg/kg of body weight) has been shown significantly decreased the serum glucose level in normal and alloxan induced diabetic rats (Patel 2011). Slightly decreased blood glucose level was found in rats after oral administration of fresh leaves extract (Arya et al., 2012).

\section{Thrombolytic activity}

Crude methanolic extract of $P$. hysterophorus has been shown significant thrombolytic effect comparable to standard thrombolytic agent, streptokinase (Al-mamun et al., 2010) Parthenolide and some other metabolites were determined as the inhibitor of human blood platelet function (Hewlett et al., 1996).

\section{Pesticidal activity}

Antifeedent bioassay revealed that lactone was found to be about 2.25 times more active than parthenin against sixth-instar larvae of Spodopteralitura and pyrazoline adduct was found to be the most effective as an insecticide against the adults of store grain pest Callosobruchus maculatus (Datta 2001). Reddy et al., 2017 used pathenium against major insect pest of cruciferous crops Plutella xylostella and Aphis craccivora Koch

\section{Antifungal activity}

Antifungal potential of different extracts of $P$. hysterophorus against human pathogenic fungi were investigated (Rai 1990). The dermatophytes and other fungal pathogens 
have been found to be sensitive to sesquiterpene lactones which are present as active agent in asteraceous plant P.hysterophorus (Rai 2003).

\section{Heavy metal and dye removal}

Sulphuric acid-treated Parthenium showed nickel removal and methylene blue dye absorbing efficiency from wastewater or industrial wastes. Ni removal was maximum at $\mathrm{pH} 5.0$ and achieved within $4 \mathrm{~h}$ after the start of every experiment. Dye adsorbing ability was also found to be comparable to commercial adsorbents. The cadmium adsorbing ability of Parthenium was also explored, which was maximum at $\mathrm{pH}$ 3-4 with recovery of $82 \%$ with $0.1 \mathrm{M} \mathrm{HCl}$ as effluent (Ajmal et al., 2006; Patel, 2011). Activated carbon prepared from Parthenium showed cresol (a phenol derivative) adsorbing ability comparable to commercial grade activated carbon (Singh et al., 2008; Patel, 2011).

\section{Impacts of Parthenium}

\section{Impact on crop production}

Due to the invasive capacity and inhibitory role of allele chemicals, phenolics and sesquiterpene lactones, mainly parthenin, it inhibits the germination and growth of plants including pasture grasses, cereals, vegetables and other plant species (Veena et al., 2012). In India Parthenium hysterophorus causes a yield decline of up to $40 \%$ in agricultural crops (Khosla and Sobti, 1981). Maharjan et al., 2007 showed that increase in concentration of extract was invariably associated with decrease in germination and seedling characteristics of the crops.

\section{Impact on human and animal health}

In India, this weed has been considered as one of the greatest source of dermatitis, asthma, eye irritation, and sinusitis (hay fever) types of diseases. Pollens in contact with body causes swelling and itching of mouth and nose. Consumption of weed roots causes excessive water loss from the body due to contact of Parthenium hysterophorus causes (Oudhia and Tripathy, 1998) acute toxicity in cattle and milk becomes bitter tasting due to the presence of parthenin compound, which is also hepatotoxic in nature. Due to Contact of this weed causes inflamed udder, fever and rushes in cows, allergic inflammation in the mouth of cattle's. If it is present in animal diet then causes dermatitis with pronounced skin lesions and a significant amount (10-50\%) of Parthenium hysterophorusin the diet can kill cattle and buffalo (Veena et al., 2012) (Ahmed et al., 1988).

It is concluded that, Parthenium weed (Parthenium hysterophorus L.) is one of the most destructive invasive weeds, intimidating natural ecosystems and agroecosystems in over worldwide. The Parthenium is spread in India very fast as it is very fast in growth and produced plenty of seeds. There is the need to encourage the research on the utilizationpotential of this weed and to evaluate its efficacy on field trials. The target of controlling of Parthenium all the aspect of managing should be kept in mind that it does not make any harmful of hazardous to the environment. The various researchers are looking it to control by using it for the benefit to the humans and the environment too an integrated management system is to bedeveloped for the control and eradication of Parthenium in India.

\section{References}

Aneja, K.R., Dhawan, S.R., and Sharma, A.B., (1991). Deadly weed - Parthenium hysterophorus Linn and its distribution. Indian Journal of Weed Science. 1991, 23: 14-18.

B.A. Auld, Hooking, J. and Mc Fadyen, R.E. 
(1983) Analysis of the spread of tiger pear and Parthenium weed in Australia. Australian Weeds, 2: 56-60.

Singh RK, Kumar S, Kumar S, Kumar A. (2008). Development of parthenium based activated carbon and its utilization for adsorptive removal of p-cresol from aqueous solution. J Haz Mat; 155:523535.

dwivedi P, Vivekanand V, Ganguly R, Singh RP (2009). Partheniumsp. as a plant biomass for the production of alkalitolerantxylanase from mutant Penicillium oxalicum $\mathrm{SAU}_{\mathrm{E}}-3.510$ in submerged fermentation. Biomass Energy. 33:581-588.

Lata, H., Garg, V.K. and Gupta, R.K. (2008). Sequestration of nickel from aqueous solution onto activated carbon prepared from Parthenium hysterophorus L. J Haz Mat., 157:503-509

Reinhardt, C., Kraus, S., Walker, F., Foxcroft, L., Robbertse, P. and Hurle, K. (2004). The Allelochemical Parthenin Is Sequestered at High Level in CapitateSessile Trichomes on Leaf Surfaces of Parthenium hysterophorus. Zeitschrift fur Pflanzenkrankheiten und Pflanzenschutz Journal of Plant Diseases and Protection, 19 (Special Issue): 253- 261.

Sharma, V.K. and Sethuraman, G. (2007). Parthenium Dermatitis. Dermatitis. 18 (4): 183-190.

Oudhia, P. and Tripathi, R.S. (1998a). Allelopathic effects of Parthenium hysterophorus L. on kodo, mustard and problematic weeds. p. 136-139. In: Proc. First Int. Conference on Parthenium Management, (Vol-II). UAS, Dharwad

Oudhia, P., Kolhe, S.S. and Tripathi, R.S. (1997a). Allelopathic effect of white top (Parthenium hysterophorus L.) on chickpea. Legume Res., 20(2):117-120. Oudhia, P., Kolhe, S.S. and Tripathi, R.S. 1997b. Allelopathic effect of Parthenium hysterophorus L. on germination of Linseed. Indian J. Plant Physiol., 2(4):327-329.

Haseler, W.H. (1976). Parthenium hysterophorus in Australia. PANS (Pest Articles and News Summaries)., 22 (4): 515-517

Rodriguez, G.S. and Cepero, G.S. (1984). Number of Seeds Produced by Some Weed Species. Centro Agricola., 11(1): 45-50

Williams, J.D. and Groves, R.H. (1980). The Influence of Temperature and Photoperiod on Growth and Development of Parthenium hysterophorus. Weed Research, 20(1): 47-52.

Sankaran, K.V. (2008). Invasive Pest Fact Sheet - Parthenium hysterophorus, Carrot Weed. Accessed May 30, 2008.

Ahlawat, A.S., Dagar, J.C. and Singh, V.P. (1979). Seed Germination Studies on Parthenium hysterophorus. Proceedings of the Indian National Science Academy, Part B, Biological Sciences, 45(6): 613616.

Tamado, T., Ohlander, L. and Milberg, P. (2002a). Interference by the weed Parthenium hysterophorus L. with grain sorghum: Influence of weed density and duration of competition. Int. J. Pest Manage. 48: 183-188.

Singh, S., Yadav, A., Balyan, R.S., Malik, R.K. and Singh, M. (2004). Control of Ragweed Parthenium (Parthenium hysterophorus) and Associated Weeds. Weed Technology, 18(3): 658-664.

Maishi AI, Ali PKS, Chaghtai SA, Khan G. A. (1998) proving of Parthenium hysterophorus, L. Brit Homoeopath J. 1998; 87:17-21.

Lata H, Garg VK, Gupta RK. (2008). Sequestration of nickel from aqueous solution onto activated carbon prepared from Parthenium hysterophorus L. J Haz Mat. 2008; 157:503-509.

De La Fuente J R, NovaraL, Alarcon SR, Diaz O J, Uriburu M L, Sosa VE (1997). Chemotaxonomy of Parthenium: $P$. hysterophorus $-P$. glomeratum. Phytochemistry; 45:1185-1188.

Gupta N, Martin BM, Metcalfe DD, Subba Rao PV (1996). Identification of a novel hydroxyproline-rich glycoprotein as the 
major allergen in Parthenium pollen. $\mathrm{J}$ Allergy ClinImmunol; 98:903-912.

Das B, Reddy VS, Krishnaiah M, Sharma AVS, Ravi Kumar K, Rao JV, Sridhar V (2007). Acetylated pseudoguaianolides from Parthenium hysterophorus and their cytotoxic activity. Phytochemistry; 68:2029-2034.

Venkataiah B, Ramesh C, Ravindranath N, Das B. Charminarone, a secopseudoguaianolide from Parthenium hysterophorus. Phytochemistry. 2003; 63:383-386.

Chhabra BR, Kohli JC, Dhillon RS (1999). Three ambrosanolides from Parthenium hysterophorus. Phytochemistry 52:13311334

Gunaseelan VN (1987). Parthenium as an additive with cattle manure in biogas production. Biol Wastes; 21:195-202.

Morin L, Reid AM, Sims-Chilton NM, Buckley YM, Dhileepan K, Hastwell GT, Nordblom TL, Raghu S (2009). Review of approaches to evaluate the effectiveness of weed biological control agents. Biol Control; 5:1-15.

Akhtar N, Satyam A, Anand V, Verma KK, Khatri R, Sharma A (2010). Dysregulation of $\mathrm{T}_{\mathrm{H}}$ type cytokines in the patients of Parthenium induced contact dermatitis. ClinChimicaActa; 411:20242028.

Narasimban TR, Murthy BSK, Harindramath N, Rao PVS. Characterization of a toxin from Parthenium hysterophorus and its mode of excretion in animals. $\mathrm{J}$ Biosci. 1984; 6:729-738.

Maishi AI, Ali PKS, Chaghtai SA, Khan G. A proving of Parthenium hysterophorus, L. Brit Homoeopath J. 1998; 87:17-21.

Towers GHN, Subbha Rao PV (1992) Impact of the pan-Tropical weed, $P$. hysteroporus $\mathrm{L}$. on human affairs. In: Richardson RG (ed) Proceedings of the first international weed control congress, Melbourne, Australia, Weed science society of Victoria, pp 134-13.

Ramos A, Rivero R, Victoria MC, Visozo A, Piloto J, Garcia A (2001). Assessment of mutagenicity in Parthenium hysterophorus L. J Ethnopharmacol; 77:25-30.

Sharma VK, Sethuraman G, Bhat R (2005). Evolution of clinical pattern of parthenium dermatitis: a study of 74 cases. Contact Derma;53:84-88

Sriramarao P, Prakash O, Metcalfe D, Subba Rao P (1993). The use of murine polyclonal anti-idiotypic antibodies as surrogate allergens in the diagnosis of Parthenium hypersensitivity. J Allergy Clin Immunol;92:567-580

Dhileepan K. Seasonal variation in the effectiveness of the leaf-feeding beetle Zygogrammabicolorata(Coleoptera:

Chrysomelidae) and stem-galling moth Epiblemastrenuana (Lepidoptera: Tortricidae) as biocontrol agents on the weed Parthenium hysterophorus (Asteraceae) Bull Entomol Res. 2003; 93:393-401.

Dhileepan K. Current status of the stem-boring weevil Listronotussetosipennis (Coleoptera: Curculionidae) introduced against the weed Parthenium hysterophorus (Asteraceae) in Australia. Biocontrol Sci Technol. 2003; 13:3-12.

Dhileepan K, Strathie L. Parthenium hysterophorus L. (Asteraceae) In: Muniappan R, Reddy DVR, Raman A, editors. Biological control of tropical weeds using arthropods. UK: Cambridge University Press; 2009. pp. 272-316

Surib-Fakim A, Swerab MD, Gueho J, Dullo E. Medicinal plants of Rodrigues. Int $\mathbf{J}$ Pharmacogn. 1996; 34:2-14.

Maishi AI, Ali PKS, Chaghtai SA, Khan G. A proving of Parthenium hysterophorus, L. Brit Homoeopath J. 1998; 87:17-21.

Das B, Reddy VS, Krishnaiah M, Sharma AVS, Ravi Kumar K, Rao JV, Sridhar V. Acetylated pseudoguaianolides from Parthenium hysterophorus and their cytotoxic activity. Phytochemistry. 2007;68:2029-2034

Ramos A, Rivero R, Visozo A, Piloto J, Garcia A. Parthenin, a sesquiterpene lactone of Parthenium hysterophorus L. is a high 
toxicity clastogen. Mut Res. 2002; 514:19-27.

Patel VS, Chitra VP, Prasanna L, Krishnaraju V. Hypoglycemic effect of aqueous extract of Parthenium hysterophorus L. in normal and alloxan induced diabetic rats. Ind J Pharmacol. 2008; 40:183-185.

Dwivedi P, Vivekanand V, Ganguly R, Singh RP. Parthenium sp. as a plant biomass for the production of alkalitolerantxylanase from mutant Penicillium oxalicum $\mathrm{SAU}_{\mathrm{E}^{-}}$ 3.510 in submerged fermentation. Biomass Energy. 2009; 33:581-588.

Gunaseelan VN. Parthenium as an additive with cattle manure in biogas production. Biol Wastes. 1987;21:195-202

Maishi AI, Ali PKS, Chaghtai SA, Khan G. A proving of Parthenium hysterophorus, L. Brit Homoeopath J. 1998; 87:17-21.

Mane JD, Jadav SJ, Ramaiah NA. Production of oxalic acid from dry powder of Parthenium hysterophorusL. J Agric Food Chem. 1986; 34:989-990.

Valdés A.F.-C, Martínez J.M, Lizama R.S, Gaitén Y.G, Rodríguez D.A, Payrol J.A. (2010). In vitro antimalarial activity and cytotoxicity of some selected Cuban medicinal plants. Revista Do Instituto De Medicina Tropical De São Paulo. 52: 101.

Talakal, T.S, Dwivedi, S.K, Sharma, S.R. (1995). In vitro and in vivo therapeutic activity of Parthenium hysterophorus against Trypanosomaevansi. Indian Journal of Experimental Biology. 33: 894-896.

Zaheer Z, Shafique S, Shafique S, Mehmood T. (2012). Antifungal potential of Parthenium hysterophorus L. plant extracts against Fusarium solani. Scientific Research and Essays. 7: 20492054.

Kumar S, Singh A.P, Nair G, Batra S, Seth A, Wahab N, Warikoo R. (2011). Impact of Parthenium hysterophorus leaf extracts on the fecundity, fertility and behavioural response of Aedesaegypti L. Parasitology Research. 108: 853-859.

N A, H F, B H A, S, F. (2010). Efficient free radical scavenging activity of Ginkgo biloba, Stevia rebaudiana and Parthenium hysterophorus leaves through DPPH (2, 2-diphenyl-1 picrylhydrazyl). International Journal of Phytomedicine. 2: 231-239.

Priya V, Radhika Srinivasa. (2011). Evaluation of invitro free radical scavenging activity of different organic extracts of Parthenium hysterophorus leaves. International Journal of Pharmacy \& Pharmaceutical Sciences. 3: 135-138.

Pandey, K., Sharma, P.K., and Dudhe, R. (2012). Antioxidant and antiinflammatory activity of ethanolic extract of Parthenium hysterophorus L. Asian Journal of Pharmaceutical and Clinical Research. 5: 28-31.

Patel, S. (2011). Harmful and beneficial aspects of Parthenium hysterophorus: an update. Biotech. 1: 1-9.

Arya A, Abdullah M.A, Haerian B.S, Mohd M.A. (2012). Screening for Hypoglycemic Activity on the Leaf Extracts of Nine Medicinal Plants: InVivo Evaluation. E- Journal of Chemistry. 9: 1196-1205.

Hewlett M.J, Begley M.J, Groenewegen W.A, Heptinstall S, Knight D.W, May J, Salan U, Toplis D. (1996). Sesquiterpene lactones from feverfew, Tanacetum parthenium: isolation, structural revision, activity against human blood platelet function and implications for migraine therapy. Journal of the Chemical Society, Perkin Transactions. 1: 1979.

Datta, S, Saxena, D.B. (2001). Pesticidal properties of parthenin (from Parthenium hysterophorus) and related compounds. Pest Management Science. 57: 95-101.

Rai M.K, Upadhyay S.K. (1990). In vitro efficacy of different extract of Parthenium hysterophorus Linn. Against human pathogenic fungi using different techniques. Indian J. Pathology and Microbiology. 33 (2): 179-181.

Rai M.K, Deepak Acharya, Wadegaonkar P. (2003). Plant derived antimycotics: Potential of Asteraceous plants. In Plant derived antimycotics: Current Trends and 
Future prospects: Howorth Press, NYork, Londin, Oxford, pp.; 165-185.

Ajmal, M., R.A.K. Rao, R. Ahmad and M.A. Khan, 2006. Adsorption studies on Parthenium hysterophorous weed: Removal and recovery of Cd (II) from wastewater. J. Hazard. Mater. 135:242248.

Patel, S., 2011. Harmful and beneficial aspects of Parthenium hysterophorus: An update. 3Biotech. 1:1-9.

Singh, R.K., S. Kumar, S. Kumar and A. Kumar, 2008. Development of partheniumbased activated carbon and its utilization for adsorptive removal of $\mathrm{p}$ cresol from wastewater. J. Hazardous Mater. 155: 523-535.

Veena, B., Kushwaha and ShivaniMaurya (2012) Biological utilities of Parthenium hysterophorus. Journal of Applied and Natural Science. 4(1): 137-143.

Khosla, S.N. and Sobti, S.N. (1981) Effective control of Parthenium hysterophorus L. Pesticides.15, 18-19.

Maharjan, S,, Shrestha, B.B., Jha, P.K. (2007)
Allelopathic effects of aqueous extract of leaves germination and seedling growth of some of Parthenium hysterophorus L. on seed cultivated and wild herbaceous species. Scientific World. 5(5): 33- 39.

Oudhia, P., Tripathi, R.S. (1998) Proc. First Int. Conf. on Parthenium Management, University of Agril. Sciences, Dharwad, India, 6-8.136 - 139.

Ahmed, M.N., Rao, P.R. and Mahender, M. (1988) Experimental introduction of acute toxicity in buffalo calves by feeding Parthenium hysterophorus Linn. Indian Journal of AnimalSciences.58:731-734.

Dhileepan K. 2009. Managing Parthenium hysterophorusacross landscapes: limitations and prospects, pp. 227-260. In: Inderjit S. (Ed.), Management of invasive weeds, Invading Nature Springer Series in Invasion Ecology, Vol. 5, Springer Science.

Nath R (1988). Partheniumhysterophorus L. A general account. Agricultural Review, 9 (4), 171-179.

\section{How to cite this article:}

Alka Sahrawat, Jyoti Sharma, Siddarth Nandan Rahul, Snigdha Tiwari and Rai, D.V. 2018. Parthenium hysterophorus Current Status and Its Possible Effects on Mammalians- A Review. Int.J.Curr.Microbiol.App.Sci. 7(11): 3548-3557. doi: https://doi.org/10.20546/ijcmas.2018.711.407 